\title{
UNMAKING THE COMMONS
}

\section{Collective Action, Property Rights, and Resource Appropriation among (Agro-) Pastoralists in Eastern Ethiopia}

\author{
Fekadu Beyene, Haramaya University, Ethiopia \\ Benedikt Korf, University of Zurich, Switzerland
}

The CGIAR Systemwide Program on Collective Action and Property Rights (CAPRi) is an initiative of the 15 centers of the Consultative Group on International Agricultural Research (CGIAR). The initiative promotes comparative research on the role of property rights and collective action institutions in shaping the efficiency, sustainability, and equity of natural resource systems. CAPRi's Secretariat is hosted within the Environment and Production Technology Division (EPDT) of the International Food Policy Research Institute (IFPRI).

CAPRi Working Papers contain preliminary material and research results. They are circulated prior to a full peer review to stimulate discussion and critical comment. It is expected that most working papers will eventually be published in some other form and that their content may also be revised (http://dx.doi.org/10.2499/CAPRiWP88)

Copyright (c) June 2008. International Food Policy Research Institute. All rights reserved. Sections of this material may be reproduced for personal and not-for-profit use without the express written permission of but with acknowledgment to IFPRI. To reproduce the material contained herein for profit or commercial use requires express written permission. To obtain permission to reprint, contact the IFPRI Communications Division at ifpri-copyright@cgiar.org.

\section{CGIAR Systemwide Program on Collective Action and Property Rights (CAPRi)}

C/- International Food Policy Research Institute, $2033 \mathrm{~K}$ Street NW, Washington, DC 20006-1002 USA

$\mathrm{T}+1202.862 .5600 \bullet \mathrm{F}+1202.467 .4439 \bullet$ www.capri.cgiar.org 


\section{ABSTRACT}

In Ethiopian development policies, pastoralist areas have recently attracted more attention. However, much debate and policy advice is still based on assumptions that see a sedentary lifestyle as the desirable development outcome for pastoralist communities. This paper investigates current practices of collective action and how these are affected by changing property rights in the pastoralist and agropastoralist economies of three selected sites in eastern Ethiopia. We describe forms of collective action in water and pasture resource management and analyze how changing property rights regimes affect incentives for collective action. We illustrate the distributional effects these practices are having on (agro-) pastoralist communities and how these practices are being influenced by the broader political and economic dynamisms of the area.

Keywords: pastoralism, collective action, property rights, conflict, Ethiopia, water management, rangelands management 


\section{ACKNOWLEDGMENTS}

We would like to thank Tobias Hagmann, Esther Mwangi, and one anonymous referee for incisive suggestions on earlier drafts of this paper, and Ayalneh Bogale, Bekele Hundie, Konrad Hagedorn, and Martina Padmanabhan for continuous exchange and collaboration. This research was funded by the Federal Ministry for Economic Cooperation and Development, Germany. 


\section{Table of Contents}

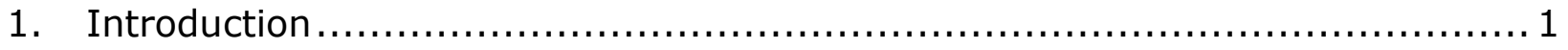

2. Pastoralism, Property Rights and Collective Action .............................. 2

3. The Study Sites and Research Methods ........................................ 4

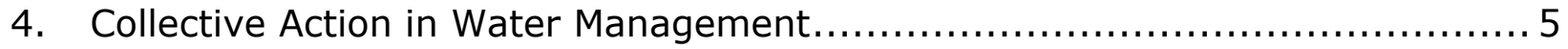

5. Multiple Artifacts, Multiple Uses, Multiple Rules .............................. 12

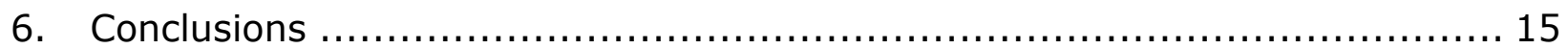

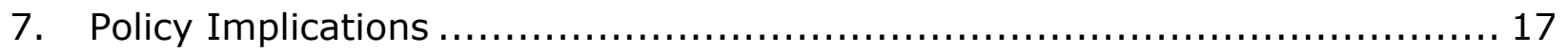

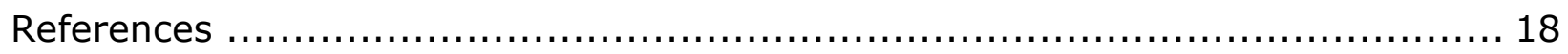




\section{UNMAKING THE COMMONS}

Collective Action, Property Rights, and Resource Appropriation among (Agro-) Pastoralists in Eastern Ethiopia

Fekadu Beyene and Benedikt Korf ${ }^{1}$

\section{INTRODUCTION}

In Ethiopian development policies, pastoralist areas have recently attracted more attention. Funding for (agro-) pastoralist development has increased significantly in the past decade. However, much debate and policy advice is still based on stereotypical representations of "pastoralist" areas (as backwards, prone to starvation and food insecurity, hotbeds of violent conflict and contraband trade), on modernist thinking among the ruling elite that considers pastoralism to be an outdated mode of life that needs to be directed toward the path of modernity (for example, sedentary farming or urban life) and on technical interventions that focus on (partial) sedentarization of pastoralists (for example, making them "agropastoralists" who only move livestock, but not their homes) (Hagmann, 2006; Arsano Yacob, 2000; Fekadu Beyene, 2000; FDRE, 2002, 2003; Hogg, 1996; Moris, 1999). A kind of highlander (sedentary farming) versus lowlander (pastoralist) dichotomy continues to prevail in public discourse and provides a discursive "clash of civilizations" between the ruling elite that originates from the highlands and the Somalis (and other pastoralist lowlanders) who consider themselves as politically marginalized (Mohammud Abdulahi, 2004; Ayalew, 2001; Manger, 2000; Hogg, 1997).

This "highland" bias (Arsano Yacob, 2000) in the state's policies and politics toward the pastoralist lowlands has resulted in land tenure policies that have largely ignored the specificities of the pastoralist lowlands (Fekadu Beyene, 1994; Helland, 2006; Mohammud Abdulahi, 2007) and have continued to consider sedentarization as the precondition of progress in the pastoral rangelands (FDRE, 2003:31; Moris, 1999:51). Typically, the state aided the expansion of agriculture into the lowlands, but failed to regulate the tenure transformations that accompanied the diversification of rural resource use (Hagmann, 2006). The arid and semi-arid lowlands continue to be considered as a reserve of "large tracts of unsettled land" to be developed through sedentarization and agricultural resource use, best through irrigated cultivation along the river banks (FDRE, 2003:31, cited in Hagmann, 2006:210; Haldermann, 2004; Moris, 1999).

Somali region and the borderlands from neighboring regions, such as Oromyia, experience a precarious statehood, where the power of the (regional) state is limited in spatial outreach and at times appears to be superimposed from outside forces. While Somali region has been sidelined in national politics, it is at the same time of strategic importance to the central state. Somalis have often been suspected of not being reliable citizens, because of their links with neighboring

\footnotetext{
${ }^{1}$ Corresponding author: korf@geo.uzh.ch
} 
Somalia - a legacy from the Ethiopian-Somali or Ogaden war of 1977 and 1978 and the continuing ideology of "Greater Somalia" that still finds support among Somalis living in Ethiopia. The central state considers pastoralist movements across borders as potentially a problem undermining its border control and economic resource base. The central policy of ethnic federalism has opened up new struggles among clan groups over access to the state's financial resources on the regional and woreda levels - a struggle that is largely fought through expansion of territorial control (sole possession or occupation of a territory) as the basis for the state's allocation of financial resources (Hagmann, 2005, 2007; Samatar, 2004).

In Somali and neighboring regional states, property rights to land are undergoing significant transformation that goes hand in hand with dynamic economic changes. Peri-urban places in pastoralist areas have become important market locations for cross-border exchange of livestock products and trading goods. New economic elites invest in peri-urban places and their surrounding spaces, whereby land tenure relations shift from communal and collective use to enclosed and individual use (rights). The influx of capital encourages opportunistic exploitation of ecological resources, for example charcoal production for export to Somaliland and the Gulf states. At the same time, the (agro-) pastoralist livestock economies continue to struggle for survival at the resource margins, hampered by repeated droughts in the last decades (Devereux, 2006; Hagmann, 2006).

These are, indeed, challenges to pastoralist livelihoods in those locations begging the question: How do pastoralist and agro-pastoralist households cope with and adapt to these livelihood shocks, be they natural (droughts, disease) or political (violent conflict, precarious statehood)? This paper investigates current practices of collective action and how these are affected by changing property rights in the pastoralist and agro-pastoralist economies of three selected sites in eastern Ethiopia. This paper describes forms of collective action in water and pasture resource management and analyzes how changing property rights regimes affect incentives for collective action. Additionally it illustrates the distributional effects these practices are having on (agro-) pastoralist communities and how these practices are being influenced by the broader political and economic dynamisms of the area.

\section{PASTORALISM, PROPERTY RIGHTS AND COLLECTIVE ACTION}

Collective action can be understood as an action taken by a group of individuals to achieve common interests (Marshall, 1998). These individuals sharing a common goal or interest are characterized by well-defined group membership or boundaries without necessarily encompassing the whole society. In pastoralist economies, collective action is essential for managing natural resources for livestock herding, in particular water and pasture. ${ }^{2}$ Property rights to natural resources do not necessarily imply sole authority to use and dispose of a resource (equating to full ownership), but these rights are often differentiated according to specific users and benefit streams. Property rights are relational in the sense that they define rights and duties of an individual vis-à-vis a collective (Bromley, 1991). In pastoralist

\footnotetext{
${ }^{2}$ As well as herding itself, though it is not subject to the analysis in this chapter.
} 
societies, many resources are based on communal property rights, meaning those resources used by a group of users, normally the (sub) clan who holds customary rights over a specified territory. Secondary user rights exist in territories held by other clans. Secondary access and user rights are subject to negotiation with the primary rights holders.

In the theoretical literature on collective action, a number of factors have been identified that induce cooperative behavior in natural resource management: asset ownership (McCarthy, 2004; Place et al., 2004; Aggarwal, 2000), homogeneity of group members (Banerjee et al., 2004; Gächter et al., 2004; Bardhan, 2000; Dayton-Johnson, 2000), mutual vulnerability of group members (Singleton and Taylor, 1992) and dependence on the resources (Runge, 1986; Wade, 1987). In addition, Ostrom (1998) has emphasized the institutional arrangements that induce cooperative behavior. Elements of these arrangements include establishment of penalty systems and enforcement of rules (Grebremedhin et al., 2004), social norms (Cleaver, 2000) and encouragement by peer groups (Kandel and Lazear, 1992). The latter factors are particularly important, because interaction among group members is not confined to activities in resource management, but embedded in broader social networks. Benin and Pender (2006), for example, demonstrate that even in the absence of monitoring, rule violations can be limited when rule obedience is based on mutual trust that others would do the same.

The mobile, transhumant mode of livestock keeping of (agro-) pastoralist livelihoods demands a flexible tenure regime based on non-exclusive use rights to pasture and water resources (Cousins, 1996; Scoones and Graham, 1994). Rules governing access to resources are flexible, based on multiple negotiations and rules (Thebaud and Batterbury, 2001). These flexible access regimes of property rights are practiced through social networks of kinship and economic exchange where settlement and mobility patterns of members of a group favor a spatially diversified risk-sharing arrangement to adapt to erratic climatic conditions (Vanderlinden, 1999). These access regimes are based on the principle of reciprocity and balance out rights and duties of different groups (primary and secondary rights holders to specific resources). There is often an implicit assumption in these studies that livelihoods in those environments were static in their rules, norms and practices (the so-called "customary" practices), although many pastoralist societies are undergoing dynamic processes of social and economic transformation. More recently, market-based, individualized arrangements have emerged in the form of contract grazing (Ngaido, 1999; Vedeld, 1998), where outsiders (secondary rights holder) pay grazing fees to insiders (primary rights holder), meaning those holding customary property rights, or where secondary rights holders share benefits with primary rights holders that they derive from using communal resources of another group (Ayalneh and Korf, 2007).

In eastern Ethiopia, embedded customary practices in the management and use of the pastoral commons involve various forms of collective action that are governed by a set of rules. These practices have evolved in parallel to environmental stress (drought), political vulnerability (violent conflict, precarious statehood) and economic threats and opportunities (such as contraband trade). These kinds of stress and instability are endemic to pastoral lives in Somali region and the borderland of Oromiya region with Somali region. They are not of recent 
origin as is often implicitly or explicitly assumed, but their dynamics and significance for the lives and vulnerabilities of pastoralists has changed (Kassa et al., 2005). What sorts of collective action prevail, how do changes in property rights affect incentives for collective action and what are the distributional consequences in the welfare of pastoralist households? These are the core questions that we will investigate.

\section{THE STUDY SITES AND RESEARCH METHODS}

This case study focuses on three districts (woreda) in eastern Ethiopia: Mieso (Oromia region, formerly jointly administered with Somali region), Kebribeyah and Harshin (both Somali region). These three sites represent different (agro-) pastoralist household economies and political settings that demonstrate the complexity of (agro-) pastoralism in the semi-arid parts of eastern Ethiopia, which have reasonable market access. In Mieso, we have studied agro-pastoralists belonging to the Oromo ethnic group, whereas in Kebribeyah, agro-pastoralists are from the Somali ethnic group as are the pastoralists from Harshin, although the latter two belong to different clans. While the term "agro-pastoralist" has also a political connotation in Ethiopian politics (because it implies a linear progressive advancement from pastoralism toward agro-pastoralism toward sedentary farming, and this kind of thinking is believed to drive the mindset of Ethiopian policy makers), the term is here utilized to differentiate the household economies. Agropastoralist means a household, which derives a significant part of its income from farming activities, whereas it is very low in the case of a pastoralist household, that is, pastoralist households may also do some farming, but to a lesser extent.

Table 1: Background of the three study sites

\begin{tabular}{|c|c|c|c|}
\hline Location & Mieso & Kebribeyah & Harshin \\
\hline Household economy & Agro-pastoralist & Agro-pastoralist & pastoralist \\
\hline $\begin{array}{l}\text { Ethnic and clan } \\
\text { groups }\end{array}$ & $\begin{array}{l}\text { Oromo, Ittu, Alan and } \\
\text { Nole }\end{array}$ & $\begin{array}{l}\text { Somali, Abskul and } \\
\text { others (Akisho, } \\
\text { Bartere and Ogaden) }\end{array}$ & $\begin{array}{l}\text { Somali, Isaaq and } \\
\text { others }\end{array}$ \\
\hline Kebeles ${ }^{3}$ studied & 4 & 2 & 2 \\
\hline $\begin{array}{l}\text { No. of households } \\
\text { interviewed }\end{array}$ & 80 & 40 & 39 \\
\hline $\begin{array}{l}\text { Pastoralist water } \\
\text { management issues } \\
\text { studied }\end{array}$ & $\begin{array}{l}\text { Communal ponds; } \\
\text { communal wells }\end{array}$ & $\begin{array}{l}\text { Communal ponds, } \\
\text { communal wells, } \\
\text { private \& communal } \\
\text { cisterns }\end{array}$ & $\begin{array}{l}\text { communal wells; } \\
\text { private \& communal } \\
\text { cisterns }\end{array}$ \\
\hline Location & $\begin{array}{l}\text { Borderland of Somali } \\
\text { and Oromiya regions, } \\
\text { close to } \\
\text { highway/railway to } \\
\text { Addis Ababa road }\end{array}$ & $\begin{array}{l}55 \mathrm{~km} \text { east of the } \\
\text { regional capital Jijiga }\end{array}$ & $\begin{array}{l}\text { Borderland with } \\
\text { Somaliland ( } 30 \mathrm{~km} \\
\text { afar) - trading routes } \\
\text { mainly to Hargesa, } \\
\text { Somaliland }\end{array}$ \\
\hline
\end{tabular}

Source: own research

The region is considered to be semi-arid with a bi-annual rainfall pattern ( $g u$ rains from March to June and deyr rains from October to November) with a mean annual precipitation ranging from 600-700 mm. The annual precipitation,

${ }^{3}$ Kebele is the lowest formal administrative unit also termed as 'peasant association'. 
temperatures and as a result the rangeland capacities vary significantly between the different locations and from year to year. Overall, Somali region has experienced repeated droughts in recent decades. This has severely affected stock levels and the resource base. While the literature on pastoralism tends to emphasize climatic risk (Little et al., 2001), a historical comparison of rainfall patterns by Devereux (2006) indicates that rainfall has not been more erratic than in previous periods, hence that the exposure to climatic variability and drought has been a persistent feature in Somali region.

To collect data we employed a mixed methods consisting of: (1) focused group discussions using rapid rural appraisal techniques to familiarize research team and the local population, to gain a basic understanding of community perceptions, needs and aspirations, to collect basic information on demographic and socio-economic characteristics of the communities; (2) a detailed household survey where we gathered data on assets, incentives and opportunities of households in resource management. Household data were collected with the support of enumerators and experienced translators; and (3) key informant interviews with government bureaucrats, NGO staff, local elders and other key informants generated information on institutions of resource governance. Data were collected in two phases: in the first field phase (2004-05), the focused group discussions, the household survey and selected key informant interviews were carried out. The second field phase (July to August, 2006) focused on key informant interviews to complement the prior data collection and on filling specific knowledge gaps.

Consequently, we undertook a qualitative in-depth analysis of selected cases and looked into the specific factors that affect the rules governing collective action and property rights. The latter also allowed some analysis of the distributional effects of these institutional arrangements. In particular, we used a comparative approach to sort out similarities and differences across the study sites with respect to the different resource management practices and property rights arrangements as well as the different technological artifacts that are in use for water management. Our empirical study provides a one-shot collection of perceptions, assets and rules - with retrospective information on the past. It cannot deliver an in-depth longer-term perspective of historical changes over the last decades, a weakness shared by many similar studies on livelihoods.

\section{COLLECTIVE ACTION IN WATER MANAGEMENT}

Two types of resources are essential in the (agro-) pastoralist livestock economy: (1) pasture and fodder and (2) water (for livestock and farming). Mobility patterns across seasons and across different years need to take account of both resource types. A herder's possibility to transform pasture resources into economic value depends on the quality of the pasture as much as on the availability of water, because both are complementary inputs to livestock production. Management of water sources and water points has become even more important due to erratic rainfall patterns. Collective action around water sources is point or location specific, meaning water sources are spatially fixed (immobile), whereas collective action relating to herd management requires spatial mobility and therefore different organizational forms of collective action. 
We study here three types of technical artifacts that make water available for various uses: ponds, cisterns and wells. Each of the three types is governed through different sets of rules-in-use and practices. These will be discussed in the subsequent sections which discuss the (i) physical attributes of the artifacts, (ii) rights and duties and (iii) the political economy of practices of collective action and property rights changes.

\section{Wells}

Hand-dug wells are a very important communal water source for livestock and human consumption. Wells are traditionally established, managed and used by a group. They are often located far away from settlements on strategic places of mobility routes of livestock herding. Traditional wells have been a common feature in pastoralist livelihoods in the last decades and centuries and some wells can look back to more than hundred years of lifespan as reports of early travelers to the region indicate. While wells are a well-established artifact to use water for human and livestock consumption, elders report about declining levels of maintenance of communal wells. Why is it that traditional rules governing maintenance and use of traditional wells for so long have partially become ineffective or less efficient?

Physical attributes - hand-dug wells vary in depth. Well discharge depends on its depth and the users' ability to manage it. Digging deeper wells is costly and requires extensive labor, but maintenance is easier compared to ponds. Elders from Mieso reported that in their locality, a properly managed well can serve its purpose for up to 60 years. This lifespan may differ in other sites. Wells, however, require high extraction costs, mostly by hand. Water extraction is highly labor intensive, in particular for watering animals. In our three study sites, Mieso and Harshen had shallower water tables compared to Kebribeyah making well construction less costly.

Rights and duties - user rules are quite differentiated, but there are some commonalities across different locations and ethnic groups. In all sites, the usual norm in defining watering priorities is "first-come, first serve" - but users with a small number of livestock usually get priority over large livestock owners, because they require relatively little time to water their animals. "Membership" is usually defined based on a household's contribution of labor to the digging and maintenance of the well. Initial well "diggers" who do not contribute to maintenance in one season are expected to do so in the following season. Repeated noncooperation will lead to access restrictions. These internal rules are tailored toward preventing continuous free-riding other than occasional contributions. There are internal informal sanctioning mechanisms in place where members observe who has done maintenance, but this seems to be upheld as a principle rather than being practiced, because in real life, it is difficult to distinguish users who have contributed to maintenance work and those who have not as the time of contribution is variable. Monitoring contribution is therefore virtually impossible. Therefore, only in principle is delineation of use rights based on the consideration of a group member's contribution to maintenance. 
The norms of access to water are differentiated taking into consideration labor investment costs and (potential) reciprocal gains. In fact, the rules and norms governing access and exclusion to well water are further differentiated beyond a cost-benefit logic that considers the contribution of users to well construction and maintenance. For instance, a household who contributes much to well maintenance may temporarily migrate away while other members are utilizing the resource. In most cases, it appears that any contributing member from a village or sub-clan can use as much water as needed irrespective of the amount of labor contributed. Poor clan members often contribute significantly although they only use small amounts of well water. They do this to gain wider social recognition within the clan. The practices of granting access to well water further consider the livelihood interdependence among clan members and with outsiders. ${ }^{4}$ While members reserve the right to exclude non-members from access to water, they do so in consideration of longer-term reciprocal relationships. Rights to access water are usually granted in expectation of future reciprocity. A good example of those reciprocal arrangements can be observed in Mieso between Ala and Ittu clans, where water tables are shallow and labor contributions for the construction was not immense. These kinds of longer-term reciprocal relations are important because of the spatially very differentiated rainfall patterns that can bring water scarcity to one location but not necessarily to another location not too far away. In other locations where water tables are deep and well construction requires high labor inputs, access to water is usually restricted or denied for non-members. This indicates that reciprocal sharing is more common where initial investment costs have been low.

Political economy - communal well management and maintenance has faced several challenges since the late 1980s, especially after the downfall of the Siad Barre regime in Somalia when violent fighting in Somalia brought a large influx of refugees to the Somali region in Ethiopia. In many sites, elders reported about declining water tables indicating over-extraction of water resources. The second challenge derives from more severe droughts in recent years that have increased the pressure on well-endowed wells. In times of crisis and feed stress, pastoralist households seek to use grazing resources and well water based on kinship relations, for example, they will access water of a well where a relative is a member, meaning where the latter has contributed to well construction and management. Those relatives from another territory are granted access to the well, although they have not contributed and are not members of the group. Mostly, elders facilitate and negotiate the decision to grant access that is then collectively binding. However, when this influx of non-members with kin relations becomes extraordinarily common, it reduces the incentives of the members to contribute their share to the maintenance of the well. In particular, when this well is located far away from the settlement area, it is used only randomly and exclusion is difficult. Collective herding, meaning several households that pool their livestock for herding, further exacerbates the pressure on water wells (extraction largely surpasses surcharge rates), because even those households who have not

\footnotetext{
4 "Outsiders" (= non-members) are those neighbors or other (sub-) clans who have not contributed.
} 
contributed can water their livestock as part of the larger pool of animals thereby gaining access to water wells that are managed by others.

Broadly speaking, it is almost impossible to exclude non-members from using well water, either because the resource location entails greater cost of monitoring or because of clan and kinship relations. It is considered to violate commonly accepted cultural norms to exclude someone who is, even remotely, related. Furthermore, especially among Somali clans, entitlements to use water are often based on multiple clan relations and social obligations, which persist over generations. Contributions from non-members that date back several decades or generations may continue to enfold access rights for the family and clan members even though the current generation has not contributed. In effect, this creates a system of customary rules where even non-members gain rights of access to well water (see also, Devereux, 2006; Hagmann, 2007; Unruh, 2005). It is not appropriate among Somali clans to exclude someone in need, in particular in times of crisis. This means, on the other hand, that incentives for members to contribute to well management declines the more often crisis situations prevail and multiple users from different clans make use of communal water wells - well water is thereby transformed from a club good to an open access resource, because the sanctions and enforcement rules for members cannot be applied to non-member, and the latter can still utilize the resource.

\section{Cisterns}

Cisterns are only constructed in Kebribeyah and Harshin, the two sites in Somali region. They are normally cemented and are locally known as birka. In these locations, birkas are often the main water supply source for livestock and humans (Boku Tache, 2000). The construction of birkas started in the 1960s, but increased significantly after the 1970 s due to increasing competition for water from communal wells between pastoralists and refugees from neighboring Somalia. Communal wells tended to deteriorate, because of neglect: the massive in-migration of refugees weakened the ability of user groups to enforce their traditional rules (Sugule and Walker, 1998). In addition, several aid agencies constructed birkas, but many of those have been abandoned due to poor maintenance. For example, many birkas in Kebribeyah disappeared due to conflicts over ownership and control after the $\mathrm{SERP}^{5}$, the aid program that had constructed the cistern, left the location. Property rights disputes around communal birkas are widespread and beg the question why it is that clan elders fail to enforce user rights and duties, although water from birkas is essential for pastoralist livelihoods.

Physical attributes - as birkas are cemented, infiltration and leakage is reduced, evaporation can also be limited by covering the cistern. In Harshen, communal cisterns can be quite large and deep, with dimensions of 30*40*4 cubic meters $\left(\mathrm{m}^{3}\right)$, private ones are typically smaller. The most expensive part of the investment is paying for skilled labor (masons) and the purchase of cement. Private birka owners either pay those skilled laborers in cash or transfer user rights to them in

\footnotetext{
${ }^{5}$ SERP $=$ South East Rangelands Project
} 
return for labor contributions. In communal cisterns, all users contribute labor and other inputs, but often, construction of communal cisterns is subsidized by aid agencies (which distorts investment costs).

Rights and duties - there are marked differences in the case of private and communal cisterns. In Kebribeyah, private cisterns are dominant, whereas in Harshen, both private and communal ones exist. In the case of private birkas, the owners use them to generate revenue and thus, are seen as profit-seeking entrepreneurs. Water users have to pay for water. Prices may vary from 5 Birr $(E T B)^{6}$ per barrel in the rainy season to 20ETB per barrel in the dry season. In some places, there are fixed rates for each animal species. Private owners normally allow their relatives to use birkas freely or levy a lower price. In communal cisterns, those who contributed labor gain access and user rights. Moreover, revenue generated from water sales to non-members, such as livestock traders crossing the area and neighboring clan members, is shared among group members.

Political economy of birka construction - the proliferation of private cisterns, in particular in Kebribeyah, in the 1980s and 90s, brought water prices down and reduced incentives to maintain communal cisterns and wells, because it was more convenient to buy water at low prices from private birkas. However, with the gradual decline of communal water points, private birka owners realized their strategic importance in supplying water. They subsequently increased water prices. Because of a decline in artifacts providing access to water, water became unaffordable during prolonged dry seasons, when it is scarce and prices are going up.

The move of wealthier clan members to construct private cisterns has been a turning point in collective action for joint management of communal water resources. Wealthier segments of the clan did not have further incentives to contribute to the maintenance of communal water points (cisterns, wells, ponds). In other words, it was the potential leadership group, the elite of the clans, who failed to deliver their share of collective action and thereby weakened the organizational capacities of the remaining clan members to act collectively for resource management. In effect, communal birka maintenance was not considered an issue for the whole clan, but for the remaining, often politically less influential and/or economically less powerful clan members. This transformation of intra-clan responsibilities and duties toward the pastoralist commons effectively changed the genealogical and social networks and connections of a rights-duties dialectic inherent in customary rules.

Cistern owners had gained strong power over a strategic resource in the pastoralist economy which potentially disfavors the poor and vulnerable clan members who depend on buying water from their cisterns (because communal water points have declined). Clan elders have often tried to negotiate with cistern owners in times of acute water scarcity to keep water prices at affordable levels for less wealthy clan members, but their action has not always been successful or only temporarily so. In Kebribeyah, clan elites have also tried to establish rules that

${ }^{6} 1$ \$ US 8.6 Birr (May 2007). 
forbid the construction of new private cisterns. Cistern owners stated they were worried that additional cisterns would further disturb the grazing patterns and reduce the availability of grazing land - it could increase pressure on the remaining pasture and lead to its eventual degradation. Cisterns also compete for watershed space, because they require a long water inflow channel. Those wishing to build new cisterns argued that the current cistern owners wanted to keep potential competitors out of the water market in order to be able to uphold water prices and secure oligopolistic gains from a limited number of cisterns.

Interestingly, in neighboring clan areas, similar agreements (not to allow establishment of new cisterns) can be found: in 1996, members of the Habr Yoonis clan in Gashamo district south of Kebribeyah made agreements not to establish new cisterns as was done in the Ogaden and Isaaq controlled territories (Sugule and Walker, 1998). The rapid spread of this rule has put pressure on clan elders in Kebribeyah to follow suit. In effect, this rule may increase wealth disparities at the expense of more vulnerable clan members, because those who in earlier years established the rule to allow construction of private cisterns now exclude potential newcomers to join the club. The bargaining power of poor and vulnerable clan members to influence the elites in rule making is thereby limited. The individualization and marketization of water as a commodity rather than as a common (club $=$ clan) good has not only increased wealth disparities, but also power differentials within the clan. It is a case of elite capture.

\section{Box 1: Communal cistern program by Oxfam}

In Harshin, Oxfam (UK) has launched a project of communal cistern construction and management for poorer pastoralists in 2002. Group members had to contribute labor and land whereas Oxfam provided funding. To pay for maintenance costs, users had to pay a (low) price for water - a management committee composed of formal elders, women, local administrators is to enforce these rules. Clan leaders insisted that communal cisterns were to be built in enclosed land (enclosure is a piece of land fenced off the communal land for private use). Group members had to select one member with a large enclosure to construct the cistern on this land. This provides the group member who owns the land with a strategic power resource, but secures property rights and deters potential disputes if cisterns were constructed on communal land. The communal cistern in this case is a club good available only to a clearly defined group of user. Non-members have to pay higher fees. Since the project has only recently been implemented, it is too early to judge its success or failure, in particular the sustainability of the committee's role in rule enforcement. The program is still ongoing and an evaluation of its sustained impacts is too early to be concluded.

\section{Ponds}

Pond construction is a low cost water harvesting technique propagated by the central government in various campaigns and regional programs of communitybased water management. This type of water harvesting technique is tailored toward increasing farm productivity and toward encouraging the production of high 
value crops. Pond construction has been a traditional water harvesting technique of agro-pastoral groups even prior to the government's intervention, but the government programs reinforced those traditions.

Physical attributes - User groups need to provide labor for the construction of the pond as well as for maintenance (silt removal, fence constructions and renewals, channel clearing). The capacity of ponds varies: on average, a communal pond contains up to $5000 \mathrm{~m}^{3}$ of water, while privately constructed ones range from 150$200 \mathrm{~m}^{3}$. If effectively managed, such ponds can retain water up to six months after the end of the major rainy season and water availability from the pond is quite predictable and reliable. At the same time, infiltration losses are high, because walls and surface of the reservoirs are generally not cemented. Even cemented ones experience water losses, because the poor soil quality leads to cracks in the cement and resulting seepage. These technical limitations are site-specific and predominant in Mieso. To reduce infiltration losses, the government propagated plastic sheets that were supplied for user groups on credit basis. However, most plastic sheets are used in private ponds rather than communal ones, because the sheets are not sufficiently large to cover larger communal ponds.

User rights and duties - A communal pond is a common property of kebele residents. The Ethiopian government has invested great efforts in encouraging the construction of communal ponds as a means of water harvesting. According to the specifications in most government-initiated programs, user groups have the duty to contribute labor during construction and for maintenance. Non-contribution will result in oral warning and financial fines. When a user remains absent during a day of communal labor, a warning is issued after the first day of absence. If he or she fails to contribute repeatedly, a fine will be imposed. The amount of fines is set in advance to avoid bias and ensure fairness. But it is subject to revision depending on a defector's health, physical ability and wealth - the rich pay higher fines. Enforcement is exercised through the "team leader" - a person selected among the users - with the support of elders. The team leader reports about payment of fines in village meetings. Poor users who cannot pay fines may compensate this by providing double amounts of labor in the future. These are the kind of rules "on paper"; they provide some flexibility to account for the specific needs of poorer group members, but enforcement is often difficult due to other social obligations and reluctance to punish.

In principle, all members who have contributed have the right to use water from communal ponds, but access to water may be prioritized among users according to criteria, such as numbers and types of animals to be watered or human versus livestock consumption. The rules (or enforcement of rules) for those who failed to contribute differ from place to place. In some locations, those who did not contribute will be excluded from water use. In other places, rather than excluding defectors, users collectively push defectors to contribute, because exclusion is difficult to enforce, first due to the organizational challenge to monitor water use and second, due to social obligations which may make it inadequate to refuse water use for a member in need. Many communal ponds are located in considerable distance to the place of residents, often in the middle of crop fields. 
Most of them are not fenced off, so that stray animals can water in the ponds and exclusion is difficult to enforce without guards, making rule enforcement costly.

Political economy - in our sample, ponds were only constructed by agropastoralists in Mieso and Kebrebeyah. Pond water allows some intensive farming and livestock keeping activities, but only in locations with good market access and natural conditions conducive to water harvesting. A number of agro-pastoralist households have started cultivating high value crops (vegetables, fruits, $k^{\prime} h a t$ ) using water from the ponds. Other agro-pastoralist households use water for livestock fattening in conjunction with intensive feeding (stalks and practicing a cut and carry system), because the road to Addis Ababa provides good market access for livestock. In areas where water from ponds supplements crop farming, oxen ownership serves as an incentive to contribute labor during pond construction. However, those households without oxen (asset-poor) often rent oxen from wealthier farmers in order to ensure their contribution to pond construction. However, not all asset-poor households are able to pay for the rental and those who cannot are potentially unable to derive benefit streams from their rights to use water - they are effectively excluded from these entitlements.

Government-led programs, such as those for water harvesting, tend to construct an additional organizational structure (for example the "team leader") and layer of rules that co-exist with the established clan rules. Users will prioritize clan rules and clan relations over rules and structures developed in the state-driven programs, as those programs are there for a short period of time only, whereas the clan, clan rules and the genealogical relations will prevail. This makes enforcement of rules difficult, because it requires the consent and tacit or explicit support from clan elders. Where the economic benefits that can be appropriated from ponds is significant, for example due to good market access, clan elders have a greater incentive to support the construction and management of ponds.

\section{MULTIPLE ARTIFACTS, MULTIPLE USES, MULTIPLE RULES}

Different artifacts are available in the pastoralist economies to make water available for human consumption, livestock watering and irrigation purposes. Differential sets of rules-in-use have emerged around these different artifacts depending on technology, social relations and economic incentives. Table 2 summarizes the attributes of the three artifacts (ponds, cisterns, wells) in use among (agro-) pastoralists across the study sites. 


\section{Table 2: Comparison of artifacts for water management}

\begin{tabular}{|c|c|c|c|}
\hline & Ponds & Cisterns & Wells \\
\hline Sites & Mieso, Kebribeyah & Kebribeyah, Harshin & All sites \\
\hline Uses & Livestock, irrigation & Livestock, water sales & Livestock, drinking water \\
\hline $\begin{array}{l}\text { Resource } \\
\text { location }\end{array}$ & On farm & $\begin{array}{l}\text { Communal and enclosed } \\
\text { land, close to settlement }\end{array}$ & $\begin{array}{l}\text { Communal land, far } \\
\text { away from settlements }\end{array}$ \\
\hline Labor inputs & $\begin{array}{l}\text { Constructing channels, } \\
\text { silt removal, fencing, } \\
\text { planting perennial trees }\end{array}$ & $\begin{array}{l}\text { Digging, cementing, } \\
\text { maintaining cracked } \\
\text { walls, sharing costs of } \\
\text { skilled labor }\end{array}$ & $\begin{array}{l}\text { Digging, covering and } \\
\text { opening, preventing } \\
\text { inflow of runoff, fencing }\end{array}$ \\
\hline $\begin{array}{l}\text { Physical } \\
\text { attributes }\end{array}$ & $\begin{array}{l}\text { Poor water retaining } \\
\text { capacity, water loss } \\
\text { through evaporation, } \\
\text { watershed required to } \\
\text { capture water inflow. }\end{array}$ & $\begin{array}{l}\text { High investment costs, } \\
\text { lower seepage. Requires } \\
\text { large watershed to } \\
\text { capture water inflow. }\end{array}$ & $\begin{array}{l}\text { High investment costs } \\
\text { (digging), but durable if } \\
\text { well maintained. Point } \\
\text { source. }\end{array}$ \\
\hline Access rules & $\begin{array}{l}\text { Members only, unclear or } \\
\text { underspecified user rules }\end{array}$ & $\begin{array}{l}\text { Members only, reciprocal } \\
\text { use for non-members, } \\
\text { water sales to non- } \\
\text { members }\end{array}$ & $\begin{array}{l}\text { Members, non-members } \\
\text { on reciprocal basis, first- } \\
\text { come, first serve" rule, } \\
\text { priority to small herds. }\end{array}$ \\
\hline Enforcement & $\begin{array}{l}\text { Enforcement through } \\
\text { fines, but exclusion } \\
\text { difficult in practice. }\end{array}$ & $\begin{array}{l}\text { Exclusion relatively easy } \\
\text { to monitor (close to } \\
\text { settlement). }\end{array}$ & $\begin{array}{l}\text { Exclusion from water use } \\
\text { close to impossible due } \\
\text { to cultural norms and } \\
\text { kinship obligations }\end{array}$ \\
\hline $\begin{array}{l}\text { Property } \\
\text { rights }\end{array}$ & $\begin{array}{l}\text { Club good, but exclusion } \\
\text { difficult to enforce }\end{array}$ & Private or communal & $\begin{array}{l}\text { Attenuated due to } \\
\text { reciprocity obligations }\end{array}$ \\
\hline $\begin{array}{l}\text { Management } \\
\text { challenges }\end{array}$ & High water losses & $\begin{array}{l}\text { Conflict of interest } \\
\text { between established } \\
\text { cistern owners and } \\
\text { potentially new ones }\end{array}$ & $\begin{array}{l}\text { High extraction costs, } \\
\text { poor maintenance, } \\
\text { disputes over who comes } \\
\text { first }\end{array}$ \\
\hline $\begin{array}{l}\text { Effects on } \\
\text { livelihoods }\end{array}$ & $\begin{array}{l}\text { Incentives for crop } \\
\text { production }\end{array}$ & $\begin{array}{l}\text { Elite capture of water } \\
\text { resources }\end{array}$ & $\begin{array}{l}\text { Reciprocity principle } \\
\text { dominates }\end{array}$ \\
\hline
\end{tabular}

Source: Focused group discussions and interviews (elders, district experts)

We can see from the three different artifacts and from the different localities that the incentives for collective action in managing water artifacts depend on economic cost-benefit considerations as well as on social norms. In all three cases, exclusion of non-members is difficult to enforce, either because it is impossible to monitor water access or because it is socially unacceptable to exclude nonmembers. This reduces the incentives to contribute to collective action in maintaining those artifacts - a problem particularly pertinent in the case of communal wells. While in the latter case, reciprocal and social obligations instill a kind of inclusive access practice, it is the opposite in the case of cisterns, where an elite of wealthy clan members has appropriated the technology of water use and established an oligopoly of cistern owners who have imposed new rules that forbid others to construct their own cisterns. In effect, we can observe here a case of elite capture that comes at the expense of poorer segments of the clan and that increases economic inequalities within clans. Constructing communal ponds has been encouraged by aid agencies and the state in order to provide access to water for poorer segments of the population. But ponds suffer from technological deficiencies (high water losses) and seem economically viable only in places with good market access and where agro-ecological conditions are conducive for vegetable production. 


\section{The dialectical relationship of water and pasture resource use}

In the (agro-) pastoral economy, access to water and pasture resources is intertwined, although access to both resources is differentially negotiated between different clans. There is a differentiated and complex customary set of rules to grant access to grazing land for secondary users, meaning those neighboring clans who ask for permission to utilize the communal grazing resources of another clan. In principle, each clan possesses primary user rights over its own clan territory and is expected to confine herd movement within the boundaries of this clan territory under "normal" conditions. Secondary user rights, meaning asking for permission to enter another clan's territory and use its communal grazing resources, is only considered adequate when the own clan territorial resources are inadequate due to drought or inaccessible due to violent conflict with other clans and often subject to prior inter-clan negotiation rituals.

The right to pasture is not necessarily linked with the right to access water points, but generally, it is granted in combination, because exclusion from water while granting access rights would make enforcement costs prohibitive and would be likely to create disputes at water points. Nevertheless, negotiating access to grazing resources is easier compared to gaining access to water points. Where water is not available from communal sources, secondary users either have to negotiate individual access to private water sources (and pay for the water) or the granting of grazing rights (including the right to use communal water sources) does not provide a sufficient condition for transforming their access rights to pasture into economically viable user rights, because of inadequate access rights to water. This situation differentiates secondary users - those wealthy enough to buy water from private cistern owners can make use of the access rights whereas less wealthy households experience an entitlement failure, meaning they are unable to grasp economic benefits from their access rights to pasture, because they lack effective entitlements to water. This condition particularly affects poorer clan members, because they cannot afford to buy water from private cistern owners.

\section{The dialectics of reciprocity and social obligation}

Negotiation is akin to inter-clan cooperation. Inter-clan cooperation is based on kinship relations and the reciprocity principle, meaning access to clan territories and its resources is granted on the expectation that similar treatment will be returned by the clan or another clan in similar conditions. Negotiations encompass discussions over the rights to use communal water points, the length of stay (extent of grazing rights), the number of livestock admitted, agreements not to trespass enclosed land of hosting clan members, complete payment of "blood money" ( $\mathrm{mag})^{7}$, and the reassurance that the livestock entering into the clan territory is healthy (to avoid spread of disease). Clans define each calendar year as normal or bad (drought) years by considering the rainfall conditions. The decision to grant or not grant access rights to secondary users depends on this assessment.

7 "Blood money" is a compensation for resolving inter-clan conflict where a clan whose member is a victim of the conflict will be paid in kind based on the extent of lives lost. 
Entrance to another clan's territory generally requires prior negotiation, even though the hosting clan is socially inclined to grant access. Violent conflict over access to pasture resources in times of crisis is very uncommon, because the entrenched moral economy inclines clans to grant access rights when another clan is in need. Violent conflict mainly emerges during the rainy season, when different clans try to expand spatial control and recognized clan territory (improving their future resource endowment) but this actually varies across locations (Fekadu Beyene and Hagedorn, 2005; Ayalew, 2001; Hagmann, 2007).

Inter-clan kinship relations are important in negotiating and differentiating access to grazing resources, meaning clan members have relatives within other clans with distinct territories. These lineages and networks across clans or subclans have played an essential role in establishing the reciprocity principle (Unruh, 1995). The Somali pastoral society is organized on a genealogical basis where lineages and their segmented units are the basis for defining rights to clan territories and their communal grazing (and water) resources (Lewis, [1961] 1999). Access to communal grazing is based on membership of a lineage responsible and capable of defending such rights against competitors. Co-users from other clans on the clan territory when based on inter-clan genealogical linkages can thereby hold primary user rights and become an important agent to negotiate secondary access rights for their fellow clan members who lack those genealogical linkages.

The spread of private enclosures in Kebribeyah and Harshen has further complicated the reciprocal system of granting access to grazing resources, because in some cases, clans have subdivided their territory and distributed the land to individual private rights holders or influential clan members have violated clan rules and created "facts on the ground" by unmaking the commons and constructing enclosure fences for cisterns or pasture. A significant part of clan territories in northern Somali region has thereby become enclosed, meaning privately owned, and thereby is not subjected to inter-clan negotiations (Hagmann, 2007). In other words, the overall availability of communal resources (pasture and water) that could be subject to reciprocal exchange in the longer term is continuously shrinking. This has created discontent with neighboring clans, because it makes mobility patterns across seasons and years more complicated and restricted and decreases the options for adapting to and coping with drought conditions. It has disturbed the customary genealogical rights-duties dialectic of reciprocal obligations based on multiplicities of relations across space and time.

\section{CONCLUSIONS}

In the beginning of this article, we have noted the widely held stereotypes about pastoralism and Somali region in Ethiopian politics. These stereotypes represent pastoralism as an outdated and anarchic lifeworld, which requires technological and managerial interventions toward sedentarization, settlement and modernity. Our empirical observations do not match these stereotypes; quite the contrary. Property rights regimes to pastoral resources have undergone dynamic changes as can be observed in Somali region, Ethiopia. These changes affect incentives for and benefits from collective action to manage the pastoral common property resources and the different technologies and artifacts that make benefit streams available 
from water and pasture use. These processes of change have further differentiated socio-economic livelihoods and capabilities within the Somali pastoralist society.

There seems to be a pertinent trend toward privatizing and individualizing benefit streams to resources, whereby rights to those benefits are individualized, but duties, such as to maintain commons resources, are externalized. We could see this in the case of private cistern construction that has reduced incentives to maintain communal wells and water points. We observe this as well in the trend toward land enclosure in some parts of Somali region. The impact of this on regulating access to the pastoral commons (pasture, water) has been problematic. It has disturbed the reciprocal resource sharing arrangements between different clans, has induced inter-clan disputes and has restricted mobility patterns and thereby coping strategies in times of resource scarcity.

De facto privatization and individualization has provided some clan members with secure access to resources and additional income, for example by selling production inputs to other users, but potentially excludes others from resource access. Such a process may affect asset-poor households in some cases, but not necessarily in all places: While wealthier households are able to pay for access to privatized resources (such as water, contract grazing), asset-poor households cannot afford to do so and experience entitlement failures and a shrinking of their coping spaces and capabilities. In particular, while inter-clan negotiation may entail access to pasture commons, asset-poor households may fail to capture the associated benefit streams, when water access is privatized and prohibitively priced. In that case, clan members may have endowments to some commons resources (here: pasture), but will not enjoy the entitlement to actual benefit streams because of exclusion from others (in this case: water).

It can be concluded that while processes of individualization and privatization of benefit streams to pastoral resources - the unmaking of the commons - disturb customarily practiced reciprocity patterns, the direct effects on the livelihoods of poor pastoralists are ambivalent. This process of privatization, individualization and enclosure - or the subdividing of the pastoralist commons (Mwangi, 2007:815) has become a widely observed phenomenon in pastoralist societies with unclear property rights, precarious statehood and ambivalent clan rule. Customary mobility patterns as a strategy of risk coping are increasingly disturbed and this increases the risk marginal pastoralist households are experiencing in the face of climatic variability. The effects of enclosure on socio-economic differentiation are complex: Some poor households also practice enclosure, which offers them control over some types of benefit streams (such as cultivation, charcoal burning). Overall, however, the enclosure and privatization process excludes many poor households from access to resources that are essential for livestock keeping (such as access to water from private cisterns for which they have to pay high prices). These distributional effects exhibit a temporality as well: some of the practices linked with privatized benefit streams are environmentally and economically unsustainable in the medium term. For example, many poor households use their enclosed land to sell its charcoal resources to private traders. This promises a short-term windfall gain, but degrades the pasture basis and deprives users from future benefit streams. 


\section{POLICY IMPLICATIONS}

Any kind of policy recommendation needs to be read within the context of the Ethiopian state's politics of pastoralist development and "ethnic federalism." Past and present land tenure policies have tended to discriminate against the communal interests of pastoralist communities (Hagmann, 2007; Helland, 2006; Mohammud Abdulahi, 2007). The federal government's policy has not yet resulted in a balanced land tenure policy on regional levels that would account for both, customary modes of communal land use and emerging trends for privatized land use (Helland, 2006). The latest version of the federal Rural Land Administration and Land Use Proclamation No. 456/2005 reinstates the doctrine that all land is state property with ambivalent effects for the communal rights of pastoralists: it is written that "[the] Government being the owner of rural land, communal rural land holdings can be changed to private holdings as may be necessary" (FDRE, 2005, para 5:3). This means that communal land can be easily appropriated for private purposes and user rights be individualized, thereby substantially weakening communally held rights.

Collective action on a local scale - cooperation among a group of users of communal resources - is insufficient to counter the unmaking of the commons. It needs to be complemented by a land tenure policy that ensures the rights of communal users. Externally induced incentives and programs for collective action to manage communal resources, such as the Oxfam program on communal cisterns in Harshen (Box 1), still have to demonstrate that they can provide a sustainable basis for an alternative communal - here confined to a sub-group of less well endowed users - form of water management that can survive in parallel with the trend of privatizing water (and subsequently pasture) access by influential, wealthy clan members. The latter process often comes at the expense of less endowed pastoralist households who lack access to clan power and financial resources to even out the diminishing returns from communally managed resources. We have seen that property rights to land and its multiple resources (including pasture, water, and wood) are central in defining incentives for collective action. Even genealogical rights-duties dialectics of reciprocal obligations - the "clan" factor in Somali society - come under scrutiny when privatization and individualization of property rights takes place.

At present, the Somali regional state has handed over definition of communal versus private user rights to clan rule with ambivalent results: Elite capture has encouraged some clan elites to drive forward a politics of enclosure, which excludes asset-poor households from benefit streams, encourages unsustainable land use practices (such as charcoal production as windfall gain) and disturbs customary reciprocity patterns among and between clans potentially encouraging violent disputes over resource access. This indicates that neither are clans and customary rule systems "innocent" or most adapted to environmental and social requirements, nor has the state found a constructive role yet in the encounter with pastoralism and clan societies. It is the re-definition of this relationship that is needed most urgently to deal with the unmaking of the commons. 


\section{REFERENCES}

Abdulahi, M. 2004. Pastoral Development Strategies and Policies in Ethiopia: A Critical Analysis. In Third National Conference on Pastoral Development in Ethiopia. Paper presented at a conference held by the Pastoralist Forum Ethiopia, December 23-24, 2003, Addis Ababa. Addis Ababa: Ethiopia Pastoralist Forum.

Aggarwal, R.J. 2000. Possibilities and Limitations to Cooperation in Small Groups: The Case of GroupOwned Wells in Southern India. Word Development 28(8): 1481-1497.

Ayalew Gebre. 2001. Pastoralism under pressure: land alienation and pastoral transformations among the Karrayu of eastern Ethiopia, 1941 to present. Aachen: Shaker.

Bardhan, P. K. 2000. Irrigation and cooperation: An empirical analysis of 48 irrigation communities in South India. Economic Development and Cultural Change 48:847-65.

Benin, S. and J. Pender. 2006. Collective action in community management of grazing lands: the case of the highlands of northern Ethiopia. Environment and Development Economics 11: 127-149.

Beyene, F. and K. Hagedorn. 2005. Inter-Ethnic Conflict on Grazing Land: An analysis of Ittu-Isaa clans' resource use relations in Mieso District, eastern Ethiopia. Paper presented at conference held by the Institut français en Afrique du Sud (IFAS-Recherche) French Embassy's aid and culture services (SCAC), FAO Harare, Centre de coopération internationale en recherche agronomique pour le développement (CIRAD), the London School of Economics(LSE) and the University of Pretoria, November 28-29, 2005, Pretoria, South Africa. Newtown, South Africa: IFAS-Recherche, Pretoria: SCAC, Harare: FAO Harare, Pretoria: CIRAD, London: LSE, Pretoria: University of Pretoria.

Bogale, A. and B. Korf. 2007. To Share or Not to Share? (Non-) Violence, Scarcity and Resource Access in Somali Region, Ethiopia. Journal of Development Studies 43(4): 743-765.

Boku Tache. 2000. Changing patterns of resource control among the Borana pastoralists of southern Ethiopia: a lesson for developing agencies. In Pastoralists and Environment. Experiences from the greater Horn of Africa. L. Manger and A.G.M Ahmed eds. Addis Ababa: OSSREA.

Bromley, D.W. 1991. Environment and Economy: Property Rights and Public Policy. Cambridge: Blackwell Publishing.

Cleaver, F. 2000. Moral ecological rationality: Institutions and the management of common property resources. Development and Change 31(2): 361-383.

Cousins, B. 1996. Conflict management for multiple resource users in pastoralist and agro-pastoralist contexts. IDS Bulletin 27(3): 41-54.

Dayton-Johnson, J. 2000. Determinants of Collective Action on Local Commons: A Model with Evidence from Mexico. Journal of Development Economics 62: 181 - 208.

Devereux, S. 2006. Vulnerable Livelihoods in Somali Region, Ethiopia. IDS Research Report 57. Brighton: Institute of Development Studies (IDS).

FDRE (Federal Democratic Republic of Ethiopia). 2003. Rural Development Policy and Strategies. Addis Ababa: Ministry of Finance and Economic Development.

FDRE (Federal Democratic Republic of Ethiopia). 2002. Statement on Pastoral Development Policy. Addis Ababa: Ministry of Federal Affairs. 
Gachter, S., B. Herrmann, and C. Thoni. 2004. Trust, voluntary cooperation, and socioeconomic background: Survey and experimental evidence. Journal of Economic Behavior and Organization 55: 505-31.

Gadamu, F. 2000. Arid Land and the Role of Pastoral Nomads in the Economic and Political Integration of the Horn of Africa with particular Reference to Ethiopia. Occasional Paper No. 15. Addis Ababa: Ethiopian International Institute for Peace and Development (EIIPD).

Gadamu, F. 1994. The Post-revolutionary Rethinking of Arid Land Policy in Ethiopia. Nomadic Peoples 34-35: 69-79.

Gebremedhin, B., J. Pender, and Girmay Tesfay. 2004. Collective action for grazing land management in crop-livestock mixed systems in the highlands of northern Ethiopia. Agricultural Systems 82: $273-290$.

Hagmann, T. 2007. Bringing the sultan back in: elders as peacemakers in Ethiopia's Somali region. In A New Dawn for Traditional Authorities? State Recognition and Democratisation in Sub-Saharan Afric,. L. Buur and H.M. Kyed, eds. New York: Palgrave.

Hagmann, T. 2006. Pastoral Conflict and Resource Management in Ethiopia's Somali Region. PhD dissertation, Switzerland: IDHEAP, Université de Lausanne.

Hagmann, T. 2005. Beyond Clannishness and Colonialism: Understanding Political Disorder in Ethiopia's Somali Region. Journal of Modern African Studies 43 (4): 509-536.

Halderman, M. 2004. The Political Economy of Pro-Poor Livestock Policy-making in Ethiopia. PPLPI Working Paper No. 19 FAO: Rome.

Helland, J. 2006. Land tenure in the pastoral areas of Ethiopia. Paper presented at the International Workshop held by Haramaya University, Universitat Bayreuth and Humboldts Universitat, October 30-31, 2006, Addis Ababa, Ethiopia. Haramaya University: Haramaya, Ethiopia, Universitat Bayreuth: Dire Dawa, Ethiopia, Humboldts Universitat: Berlin, Germany.

Hogg, R. 1997. Introduction. In Pastoralists, Ethnicity and the State in Ethiopia. R. Hogg, ed. London: HAAN Publishing.

Hogg, R. 1996. Government Policy and Pastoralism: Some Critical Issues. In Conference on Pastoralism in Ethiopia, S. Edwards and T. Mesfin, eds. Paper presented at a conference held by the Pastoralist Forum Ethiopia and the Ministry of Ethiopia, February 4-6, 1993, Addis Ababa. Addis Ababa: Pastoralist Forum Ethiopia, Addis Ababa: Ministry of Agriculture.

Kandel, E. and E.D Lazear. 1992. Peer pressure and partnerships. Journal of Political Economy 100 (4): 801-817.

Belay, K., F. Beyene, and W. Manig. 2005. Coping with Drought among Pastoral and Agro-Pastoral Communities in Eastern Ethiopia. Journal of Rural Development 28: 185-201.

Lewis, I. M. 1999 [1961]. A Pastoral Democracy: A Study of Pastoralism and Politics Among the Northern Somali of the Horn of Africa. 3rd ed. Hamburg: LIT.

Little, P.D., K. Smith, B.A. Cellarius, D.L. Coppock, and C. Barrett. 2001. Avoiding Disaster: Diversification and Risk Management among East African Herders. Development and Change 32: 401-433.

Marshall, G. 1998. A Dictionary of Sociology. New York: Oxford University Press.

Manger, L. 2000. East African Pastoralism and underdevelopment: an Introduction. In Pastoralists and Environment. Experiences from the Greater Horn of Africa, L. Manger, and A.G.M. Ahmed, eds. Addis Ababa: OSSREA. 
McCarthy, N., C. Dutilly-Diane, and B. Drabo. 2004. Cooperation, Collective Action and Natural Resource Management in Burkina Faso. Agricultural Systems 82: 233-255.

Mohammud Abdulahi. 2007. The Legal Status of the Communal Land Holding System in Ethiopia: The Case of Pastoral Communities. International Journal on Minority and Group Rights 14: 85-125.

Moris, Jon R. 1999. Under Three Flags: The Policy Environments for Pastoralism in Ethiopia and Kenya. SR/GL-CRSP Pastoral Risk Management Project Technical Report No. 04/99. Logan, Utah: Utah State University.

Mwangi, E. 2007. Subdividing the Commons: Distributional Conflict in the Transition from Collective to Individual Property Rights in Kenya's Maasiland. World Development 35 (5): 815-834.

Ngaido, T. 1999. Can pastoral institutions perform without access options? In Property Rights, Risk and Livestock Development in Africa, N. McCarthy, B. Swallow, M. Kirk, and P. Hazell, eds. Washington, D.C.: International Food Policy Research Institute.

Ostrom, E. 1998. A Behavioral Approach to the Rational Choice Theory of Collective action. American Political Science Review 92 (1): 1- 22.

Place, F., G. Kariuki, J. Wangila, P. Kristjanson, A. Makauki, and J. Ndubi. 2004. Assessing the factors underlying differences in achievement of farmer groups: methodological issues and empirical findings from the highlands of central Kenya. Agricultural Systems 82: $257-272$.

Runge, F. C. 1986. Common Property and Collective Action in Economic Development. World Development 14(5): 623-635.

Samatar, A.I. 2004. Ethiopian Federalism: Autonomy versus control in the Somali region. Third World Quarterly 25 (6): 1131-54.

Scoones, I. and O. Graham. 1994. New directions for pastoral development in Africa. Development Practice 4: $188-98$.

Singleton, S and M. Taylor. 1992. Common Property, Collective Action and Community. Journal of Theoretical Politics 4 (3): 309 - 324.

Sugule, J. and R. Walker. 1998. Changing Pastoralism in the Ethiopian Somali National Regional State. Survey Report. Addis Ababa: South East Rangelands Project and UNDP Emergencies Unit for Ethiopia.

Thebaud, B. and S. Batterby. 2001. Sahel pastoralists: opportunism, struggle conflict and negotiation: A case study from eastern Niger. Global Environmental Change 11: 69-78.

Unruh, J.D. 2005. Changing conflict resolution institutions in the Ethiopian pastoral commons: The role of armed confrontation in rule-making. GeoJournal 64: 225-237.

Unruh, J.D. 1995. Pastoralist Resource Use and Access in Somalia: A Changing Context of Development, Environmental Stress and Conflict. In Disaster and Development in the Horn of Africa, J. Sorennson, ed. London: Macmillan.

Vanderlinden, J.P. 1999. Conflicts and Co-operation over the Commons: A Conceptual and Methodological Framework for Assessing the Role of Local Institutions In Property Rights, Risk and Livestock Development in Africa, N. McCarthy, B. Swallow, M. Kirk, and P. Hazell, eds. Washington, D.C.: International Food Policy Research Institute.

Vedeld, T. 1994. The state and rangeland management: Creation and erosion of pastoral institutions in Mali. IIED Paper No. 46. Dryland Networks Programs. London: IIED. 
Wade, R. 1988. Village Republics: Economic conditions for collective action in south India. Cambridge: Cambridge University Press.

Yacob, Arsano. 2000. Pastoralism in Ethiopia: The Issues of Viability. In National Conference on Pastoral Development in Ethiopia. Paper presented at a conference held by the Pastoralist Forum Ethiopia, February 2, 2000, Addis Ababa. Addis Ababa: Ethiopia Pastoralist Forum. 


\section{LIST OF CAPRI WORKING PAPERS}

01 Property Rights, Collective Action and Technologies for Natural Resource Management: A Conceptual Framework, by Anna Knox, Ruth Meinzen-Dick, and Peter Hazell, October 1998.

02 Assessing the Relationships between Property Rights and Technology Adoption in Smallholder Agriculture: A Review of Issues and Empirical Methods, by Frank Place and Brent Swallow, April 2000.

03 Impact of Land Tenure and Socioeconomic Factors on Mountain Terrace Maintenance in Yemen, by A. Aw-Hassan, M. Alsanabani and A. Bamatraf, July 2000.

04 Land Tenurial Systems and the Adoption of a Mucuna Planted Fallow in the Derived Savannas of West Africa, by Victor M. Manyong and Victorin A. Houndékon, July 2000.

05 Collective Action in Space: Assessing How Collective Action Varies Across an African Landscape, by Brent M. Swallow, Justine Wangila, Woudyalew Mulatu, Onyango Okello, and Nancy McCarthy, July 2000.

06 Land Tenure and the Adoption of Agricultural Technology in Haiti, by Glenn R. Smucker, T. Anderson White, and Michael Bannister, October 2000.

07 Collective Action in Ant Control, by Helle Munk Ravnborg, Ana Milena de la Cruz, María Del Pilar Guerrero, and Olaf Westermann, October 2000.

08 CAPRi Technical Workshop on Watershed Management Institutions: A Summary Paper, by Anna Knox and Subodh Gupta, October 2000.

09 The Role of Tenure in the Management of Trees at the Community Level: Theoretical and Empirical Analyses from Uganda and Malawi, by Frank Place and Keijiro Otsuka November 2000.

10 Collective Action and the Intensification of Cattle-Feeding Techniques a Village Case Study in Kenya's Coast Province, by Kimberly Swallow, November 2000.

11 Collective Action, Property Rights, and Devolution of Natural Resource Management: Exchange of Knowledge and Implications for Policy, by Anna Knox and Ruth Meinzen-Dick, January 2001.

12 Land Dispute Resolution in Mozambique: Evidence and Institutions of Agroforestry Technology Adoption, by John Unruh, January 2001.

13 Between Market Failure, Policy Failure, and .Community Failure.: Property Rights, CropLivestock Conflicts and the Adoption of Sustainable Land Use Practices in the Dry Area of Sri Lanka, by Regina Birner and Hasantha Gunaweera, March 2001.

14 Land Inheritance and Schooling in Matrilineal Societies: Evidence from Sumatra, by Agnes Quisumbing and Keijuro Otsuka, May 2001.

15 Tribes, State, and Technology Adoption in Arid Land Management, Syria, by Rae, J, Arab, G., Nordblom, T., Jani, K., and Gintzburger, G., June 2001.

16 The Effects of Scales, Flows, and Filters on Property Rights and Collective Action in Watershed Management, by Brent M. Swallow, Dennis P. Garrity, and Meine van Noordwijk, July 2001.

17 Evaluating Watershed Management Projects, by John Kerr and Kimberly Chung, August 2001.

18 Rethinking Rehabilitation: Socio-Ecology of Tanks and Water Harvesting in Rajasthan, NorthWest India, by Tushaar Shah and K.V.Raju, September 2001.

19 User Participation in Watershed Management and Research, by Nancy Johnson, Helle Munk Ravnborg, Olaf Westermann, and Kirsten Probst, September 2001.

20 Collective Action for Water Harvesting Irrigation in the Lerman-Chapala Basin, Mexico, by Christopher A. Scott and Paul Silva-Ochoa, October 2001.

21 Land Redistribution, Tenure Insecurity, and Intensity of Production: A Study of Farm Households in Southern Ethiopia, by Stein Holden and Hailu Yohannes, October 2001. 
22 Legal Pluralism and Dynamic Property Rights, by Ruth Meinzen-Dick and Rajendra Pradhan, January 2002.

23 International Conference on Policy and Institutional Options for the Management of Rangelands in Dry Areas, by Tidiane Ngaido, Nancy McCarthy, and Monica Di Gregorio, January 2002.

24 Climatic Variablity and Cooperation in Rangeland Management: A Case Study From Niger, by Nancy McCarthy and Jean-Paul Vanderlinden, September 2002.

25 Assessing the Factors Underlying the Differences in Group Performance: Methodological Issues and Empirical Findings from the Highlands of Central Kenya, by Frank Place, Gatarwa Kariuki, Justine Wangila, Patti Kristjanson, Adolf Makauki, and Jessica Ndubi, November 2002.

26 The Importance of Social Capital in Colombian Rural Agro-Enterprises, by Nancy Johnson, Ruth Suarez, and Mark Lundy, November 2002.

27 Cooperation, Collective Action and Natural Resources Management in Burkina Faso: A Methodological Note, by Nancy McCarthy, Céline Dutilly-Diané, and Boureima Drabo, December 2002.

28 Understanding, Measuring and Utilizing Social Capital: Clarifying Concepts and Presenting a Field Application from India, by Anirudh Krishna, January 2003.

29 In Pursuit Of Comparable Concepts and Data, about Collective Action, by Amy Poteete And Elinor Ostrom, March 2003.

30 Methods of Consensus Building for Community Based Fisheries Management in Bangladesh and the Mekong Delta, by Parvin Sultana and Paul Thompson, May 2003.

31 Formal and Informal Systems in Support of Farmer Management of Agrobiodiversity: Some Policy Challenges to Consolidate Lessons Learned, by Marie Byström, March 2004.

32 What Do People Bring Into the Game: Experiments in the Field About Cooperation in the Commons, by Juan-Camilo Cárdenas and Elinor Ostrom, June 2004.

33 Methods for Studying Collective Action in Rural Development, by Ruth Meinzen-Dick, Monica Di Gregorio, and Nancy McCarthy, July 2004.

34 The Relationship between Collective Action and Intensification of Livestock Production: The Case of Northeastern Burkina Faso, by Nancy McCarthy, August 2004.

35 The Transformation of Property Rights in Kenya's Maasailand: Triggers and Motivations by Esther Mwangi, January 2005.

36 Farmers' Rights and Protection of Traditional Agricultural Knowledge, by Stephen B. Brush, January 2005.

37 Between Conservationism, Eco-Populism and Developmentalism - Discourses in Biodiversity Policy in Thailand and Indonesia, by Heidi Wittmer and Regina Birner, January 2005.

38 Collective Action for the Conservation of On-Farm Genetic Diversity in a Center of Crop Diversity: An Assessment of the Role of Traditional Farmers' Networks, by Lone B. Badstue, Mauricio R. Bellon, Julien Berthaud, Alejandro Ramírez, Dagoberto Flores, Xóchitl Juárez, and Fabiola Ramírez, May 2005.

39 Institutional Innovations Toward Gender Equity in Agrobiodiversity Management: Collective Action in Kerala, South India,, by Martina Aruna Padmanabhan, June 2005.

40 The Voracious Appetites of Public versus Private Property: A View of Intellectual Property and Biodiversity from Legal Pluralism, by Melanie G. Wiber, July 2005.

41 Who Knows, Who Cares? Determinants of Enactment, Awareness and Compliance with Community Natural Resource Management Bylaws in Uganda, by Ephraim Nkonya, John Pender, Edward Kato, Samuel Mugarura, and James Muwonge, August 2005.

42 Localizing Demand and Supply of Environmental Services: Interactions with Property Rights, Collective Action and the Welfare of the Poor, by Brent Swallow, Ruth Meinzen-Dick, and Meine von Noordjwik, September 2005. 
43 Initiatives for Rural Development through Collective Action: The Case of Household Participation in Group Activities in the Highlands of Central Kenya, By Gatarwa Kariuki and Frank Place, September 2005.

44 Are There Customary Rights to Plants? An Inquiry among the Baganda (Uganda), with Special Attention to Gender, by Patricia L. Howard and Gorettie Nabanoga, October 2005.

45 On Protecting Farmers' New Varieties: New Approaches to Rights on Collective Innovations in Plant Genetic Resources by Rene Salazar, Niels P. Louwaars, and Bert Visser, January 2006.

46 Subdividing the Commons: The Politics of Property Rights Transformation in Kenya's Maasailand, by Esther Mwangi, January 2006.

47 Biting the Bullet: How to Secure Access to Drylands Resources for Multiple Users, by Esther Mwangi and Stephan Dohrn, January 2006.

48 Property Rights and the Management of Animal Genetic Resources, by Simon Anderson and Roberta Centonze, February 2006.

49 From the Conservation of Genetic Diversity to the Promotion of Quality Foodstuff: Can the French Model of =Appellation d'Origine Contrôlée' be Exported? by Valérie Boisvert, April 006.

50 Facilitating Collective Action and Enhancing Local Knowledge: A Herbal Medicine Case Study in Talaandig Communities, Philippines, by Herlina Hartanto and Cecil Valmores, April 2006.

51 Water, Women and Local Social Organization in the Western Kenya Highlands, by Elizabeth Were, Brent Swallow, and Jessica Roy, July 2006.

52 The Many Meanings of Collective Action: Lessons on Enhancing Gender Inclusion and Equity in Watershed Management, by Laura German, Hailemichael Taye, Sarah Charamila, Tesema Tolera, and Joseph Tanui, July 2006.

53 Decentralization and Environmental Conservation: Gender Effects from Participation in Joint Forest Management, by Arun Agrawal, Gautam Yadama, Raul Andrade, and Ajoy Bhattacharya, July 2006.

54 Improving the Effectiveness of Collective Action: Sharing Experiences from Community Forestry in Nepal, by Krishna P. Achyara and Popular Gentle, July 2006.

55 Groups, Networks, and Social Capital in the Philippine Communities, by Marie Godquin and Agnes R. Quisumbing, October 2006.

56 Collective Action in Plant Genetic Resources Management: Gendered Rules of Reputation, Trust and Reciprocity in Kerala, India, by Martina Aruna Padmanabhan, October 2006.

57 Gender and Local Floodplain Management Institutions--A case study from Bangladesh, by Parvin Sultana and Paul Thompson, October 2006.

58 Gender Differences in Mobilization for Collective Action: Case Studies of Villages in Northern Nigeria, by Saratu Abdulwahid, October 2006.

59 Gender, Social Capital and Information Exchange in Rural Uganda, by Enid Katungi, Svetlana Edmeades, and Melinda Smale, October 2006.

60 Rural Institutions and Producer Organizations in Imperfect Markets: Experiences from Producer Marketing Groups in Semi-Arid Eastern Kenya, by Bekele Shiferaw, Gideon Obare and Geoffrey Muricho, November 2006.

61 Women's Collective Action and Sustainable Water Management: Case of SEWA's Water Campaign in Gujarat, India, by Smita Mishra Panda, October 2006.

62 Could Payments for Environmental Services Improve Rangeland Management inCentral Asia, West Asia and North Africa? by Celine Dutilly-Diane, Nancy McCarthy, Francis Turkelboom, Adriana Bruggeman, James Tiedemann, Kenneth Street and Gianluca Serra, January 2007.

63 Empowerment through Technology: Gender Dimensions of Social Capital Build-Up in Maharashtra, India, by Ravula Padmaja and Cynthia Bantilan, February 2007. 
64 Gender and Collective Action: A Conceptual Framework for Analysis, by Lauren Pandolfelli, Ruth Meinzen-Dick, and Stephan Dohrn, May 2007.

65 Gender, Wealth, and Participation in Community Groups in Meru Central District, Kenya, by Kristin E. Davis and Martha Negash, May 2007.

66 Beyond Group Ranch Subdivision: Collective Action for Livestock Mobility, Ecological Viability, and Livelihoods, by Shauna BurnSilver and Esther Mwangi, June 2007.

67 Farmer Organization, Collective Action and Market Access in Meso-America, by Jon Hellin, Mark Lundy, and Madelon Meijer, October 2007.

68 Collective Action for Innovation and Small Farmer Market Access: The Papa Andina Experience, by André Devaux, Claudio Velasco, Gastón López, Thomas Bernet, Miguel Ordinola, Hernán Pico, Graham Thiele, and Douglas Horton, October 2007.

69 Collective Action and Marketing of Underutilized Plant Species: The Case of Minor Millets in Kolli Hills, Tamil Nadu, India, by Guillaume P. Gruère, Latha Nagarajan, and E.D.I. Oliver King, M.S. Swaminathan Research Foundation, October 2007.

70 The Role of Public-Private Partnerships and Collective Action in Ensuring Smallholder Participation in High Value Fruit and Vegetable Supply Chains, by Clare Narrod, Devesh Roy, Julius Okello, Belem Avendaño, and Karl Rich, October 2007.

71 Collective Action for Small-Scale Producers of Agricultural Biodiversity Products, by Froukje Kruijssen, Menno Keizer, and Alessandra Giuliani, October, 2007.

72 Farmer Groups Enterprises and the Marketing of Staple Food Commodities in Africa, by Jonathan Coulter, October 2007.

73 Linking Collective Action to Non-Timber Forest Product Market for Improved Local Livelihoods: Challenges and Opportunities, by Heru Komarudin, Yuliana L. Siagian, and Ngakan Putu Oka, December, 2007.

74 Collective Action Initiatives to Improve Marketing Performance: Lessons from Farmer Groups in Tanzania, by James Barham and Clarence Chitemi, March 2008.

75 Sustaining Linkages to High Value Markets through Collective Action In Uganda: The Case of the Nyabyumba Potato Farmers, by Elly Kaganzi, Shaun Ferris, James Barham, Annet Abenakyo, Pascal Sanginga, and Jemimah Njuki, March 2008.

76 Fluctuating Fortunes of a Collective Enterprise: The Case of the Agroforestry Tree Seeds Association of Lantapan (ATSAL) in the Philippines, by Delia Catacutan, Manuel Bertomeu, Lyndon Arbes, Caroline Duque, and Novie Butra, May 2008.

77 Making Market Information Services Work Better for the Poor in Uganda, by Shaun Ferris, Patrick Engoru, and Elly Kaganzi, May 2008.

78 Implications of Bulk Water Transfer on Local Water Management Institutions: A Case Study of the Melamchi Water Supply Project in Nepal, by Dhruba Pant, Madhusudan Bhattarai, and Govinda Basnet, May 2008.

79 Bridging, Linking and Bonding Social Capital in Collective Action: The Case of Kalahan Forest Reserve in the Philippines, by Ganga Ram Dahal and Krishna Prasad Adhikari, May 2008.

80 Decentralization, Pro-poor Land Policies, and Democratic Governance, by Ruth Meinzen-Dick, Monica Di Gregorio, and Stephan Dohrn, June 2008.

81 Property Rights, Collective Action, and Poverty: The Role of Institutions for Poverty Reduction, by Monica Di Gregorio, Konrad Hagedorn, Michael Kirk, Benedikt Korf, Nancy McCarthy, Ruth Meinzen-Dick, and Brent Swallow, June 2008.

82 Collective Action and Property Rights for Poverty Reduction: A Review of Methods and Approaches, by Esther Mwangi and Helen Markelova, June 2008.

83 Collective action and vulnerability: Burial societies in rural Ethiopia, by Stefan Dercon, John Hoddinott, Pramila Krishnan, and Tassew Woldehanna, June 2008. 
84 Collective Action and Vulnerability: Local and Migrant Networks in Bukidnon, Philippines, by Agnes Quisumbing, Scott McNiven, and Marie Godquin, June 2008.

85 Community Watershed Management in Semi-Arid India: The State of Collective Action and its Effects on Natural Resources and Rural Livelihoods, by Bekele Shiferaw, Tewodros Kebede, and V. Ratna Reddy, June 2008.

86 Enabling Equitable Collective Action \& Policy Change for Poverty Reduction and Improved Natural Resource Management in the Eastern African Highlands, by Laura German, Waga Mazengia, Wilberforce Tirwomwe, Shenkut Ayele, Joseph Tanui, Simon Nyangas, Leulseged Begashaw, Hailemichael Taye, Zenebe Admassu, Mesfin Tsegaye, Francis Alinyo, Ashenafi Mekonnen, Kassahun Aberra, Awadh Chemangei, William Cheptegei, Tessema Tolera, Zewude Jote, and Kiflu Bedane, June 2008.

87 The Transformation of the Afar Commons in Ethiopia: State Coercion, Diversification, and Property Rights Change among Pastoralists, by Bekele Hundie and Martina Padmanabhan, June 2008. 